\title{
Life strategies of fishes in European estuaries: the functional guild approach
}

\author{
Anita Franco ${ }^{1, *}$, Michael Elliott ${ }^{2}$, Piero Franzoi ${ }^{1}$, Patrizia Torricelli ${ }^{1}$ \\ ${ }^{1}$ Department of Environmental Sciences, University of Venice, Castello 2737/b, 30122 Venice, Italy \\ ${ }^{2}$ Institute of Estuarine \& Coastal Studies, University of Hull, Hull HU6 7RX, UK
}

\begin{abstract}
The structure and functioning of estuarine fish assemblages have been analysed using data sets for 38 transitional waters covering all European latitudes, including NE Atlantic estuaries, Mediterranean lagoons and Scandinavian fjords. The fish species were assigned to functional guilds covering estuarine use, mode of feeding and reproductive strategy, thus describing the use made of transitional waters by fishes. The importance of estuaries as temporary biotopes (migration and nursery routes) for fish species has been identified together with the predominance of feeding on the detritivorous hyperbenthos and infauna. The high incidence of protective breeders in estuaries, as a mechanism to prevent the flushing out of young, has also been identified. These findings allow the validation of the functional guild approach, emphasising its use for the understanding of the functioning of estuaries and for their management and the protection of their ecological goods and services.
\end{abstract}

KEY WORDS: Fish assemblage $\cdot$ Functional groups $\cdot$ Estuary use $\cdot$ Feeding mode $\cdot$ Reproductive mode $\cdot$ European estuaries

\section{INTRODUCTION}

Estuaries play a vital role in the functioning of both marine and inland aquatic systems, by providing many marine, migratory, or estuarine species with basic requirements for their life cycle (Elliott \& Hemingway 2002, McLusky \& Elliott 2004, Rountree \& Able 2007). In addition, estuaries supply Man with extensive economic goods and services, by providing, for example, fish and shellfish, aggregates for building, and water for abstraction (McLusky \& Elliott 2004). Hence, an understanding of the ecosystem processes (i.e. the functioning) of these transitional environments is necessary to enable their protection and the sustainable management required by legislation, such as the European Union Habitats and Water Framework Directives (92/43 and 2000/60/EC).

The life strategies of estuarine organisms create the structure of the estuarine ecosystem, reflect the functioning of the estuaries and can be used to determine the spatial and temporal utilisation of the available resources of space and food. The present study there- fore investigated fish adaptations to estuarine environments, in terms of habitat use, feeding and reproduction, by applying a functional approach. It relies on the use of guilds, i.e. groups of species that overlap significantly in their niche requirements, exploiting the same class of environmental resources in a similar way (Root 1967). However, Root's concept of a guild is concerned more with the way resources are partitioned (through competitive interactions) than with how they are processed by different species, thus providing an ecosystem function (Blondel 2003). Hence, we use the term guild as a synonym for functional group, which represents the ecosystem processes the species eventually perform through resource exploitation (Blondel 2003). In this way, both the functional and structural components of the estuarine ecosystem can be defined and analysed.

Guilds have a high value as a tool for understanding the functional structure of complex ecosystems such as estuaries (Garrison \& Link 2000), especially with regard to estuarine fish assemblage studies (e.g. Elliott \& Dewailly 1995, Elliott \& Hemingway 2002, Thiel et 
al. 2003, Pombo et al. 2005, Franco et al. 2006). They may account for availability of ecological niches within the overall physico-chemical functioning of estuaries (Elliott \& Dewailly 1995).

The present paper tests and validates the fish guild approach on an extensive data set, by assessing the dominant fish life strategies in European estuaries and by comparing these results with the available knowledge on fish adaptations to transitional environments (e.g. Wootton 1999, DeMartini \& Sikkel 2006, Horn \& Ferry-Graham 2006). The term 'estuary' is used here in its broadest sense, thus being synonymous with transitional water body, as defined in the EU Water Framework Directive and including various types of estuaries, deltas, rias, fjords, fjards and lagoons (McLusky \& Elliott 2007). Other studies on European estuarine fish assemblages have used a functional approach, but most of them related to single or at most to 2 or 3 estuaries (e.g. Thiel et al. 2003, Pombo et al. 2005). Only a few assessed multiple European systems simultaneously, but focused mainly on the Atlantic seaboard (Elliott \& Dewailly 1995, Elliott \& Hemingway 2002), and there are no studies on a continental scale. The present study, therefore, analyses 38 different estuaries located along European coasts, from the Mediterranean to Atlantic, North Sea and Baltic regions, thus being the first attempt to cover the entire European region, including areas given little or no attention in previous studies.

As a first step in the analysis, functional categories were defined based on the available literature. An important starting point was the recent paper by Elliott et al. (2007), a worldwide review standardising fish guild definitions and supplying general guidelines for their use. Nevertheless, although the guild categorisation provided by these authors is of particular value in illustrating differences between the ichthyofauna in very different regions (e.g. temperate versus tropical), it is difficult to apply it to a narrower geographical range (such as that in the present paper), as highlighted by the authors themselves. Hence, in order to apply the fish guild approach to European temperate estuaries, a specific guild classification was derived, combining the critical review of these authors' with other previous classifications.

\section{MATERIALS AND METHODS}

Fish guild revision. The available knowledge on the ecology of fish species in transitional environments was used to consider 3 main functional aspects: (1) the way fish use the estuary during their whole life cycle, (2) feeding preferences and strategies and (3) reproduction. Accordingly, 20 functional categories were identified within 3 functional groupings, namely 'estuarine use functional group' (EUFG, 6 categories), 'feeding mode functional group' (FMFG, 8 categories) and 'reproductive mode functional group' (RMFG, 6 categories) (terms according to Elliott et al. 2007). The criteria for guild definition from literature revision are explained below, and the resulting group characteristics are detailed in Tables A1, A2 \& A3 of Appendix 1, available in MEPS Supplementary Material at: www.int-res.com/articles/ suppl/m354p219_app.pdf.

Estuarine use functional group. Estuaries may be used by fish species as nurseries, feeding grounds, spawning grounds, or pathways of migration (Elliott \& Hemingway 2002). Functional groups accounting for these different uses have been developed by several authors worldwide producing different categorisations (Appendix 1: Table A1). The functional groups were first divided according to the location of the species' spawning site, either within or outside the estuary. Then, the different categories were defined mainly on the basis of the type, frequency and timing of use of the estuarine environment and of the abundance in estuaries (Appendix 1: Table A1).

Feeding mode functional group. Although opportunism is widely reported for estuary-associated fish as well as for fish in general (Gerking 1994, Blaber 1997, Wootton 1999, Elliott \& Hemingway 2002, Elliott et al. 2007), intrinsic factors such as morphological and behavioural constraints set the boundaries on what food items can be taken from the environment, thus affecting the individual ability to take certain prey. Extrinsic interactions (of a species or an individual with both the environment and other community members) will also influence the diet (Elliott \& Hemingway 2002, Horn \& Ferry-Graham 2006). For example, the foraging range of the fish will affect which prey are encountered and can be potentially included in the diet. The trophic categories from literature were revised accordingly, and feeding mode functional groups were identified by combining information on predominant diet and feeding place (Appendix 1: Table A2). In this way such groups indicate the main types of food exploited by fish within estuarine environments and the estuarine compartments (e.g. pelagic, benthic) where these resources are taken.

Reproductive mode functional group. The sitespawning-selection characteristics of the eggs and embryos in relation to site features and the degree of parental care are all required to define reproductive modes in fishes (Balon 1981, Elliott \& Dewailly 1995, Blaber 1997, Wootton 1999, Elliott \& Hemingway 2002, DeMartini \& Sikkel 2006, Elliott et al. 2007). Fish species were first divided into oviparous and viviparous, according to the maternal investment in individual offspring (DeMartini \& Sikkel 2006) (Appendix 1: 
Table A3). Oviparous species, then, were further distinguished on the basis of their egg characteristics, mode of release and the degree of parental care provided to eggs (Appendix 1: Table A3).

Data set and species allocation to functional groups. A data base of the ichthyofaunal communities was created from literature on 38 European estuaries (Fig. 1, Table 1). The main characteristics of these environments are given in the source literature (Table 1). The taxonomy was standardised by removing synonyms, and the species names were updated according to Eschmeyer (2004). Each species from each estuary was assigned to one of the defined functional groups according to information on their ecology and biology. Any information on local adaptations of the species to the studied estuarine environments, where indicated by the source authors, was also used.

As regards estuarine habitat use, when no information on local adaptations was given, the species was assigned to the more frequent category attributed to it across the other investigated European estuaries.

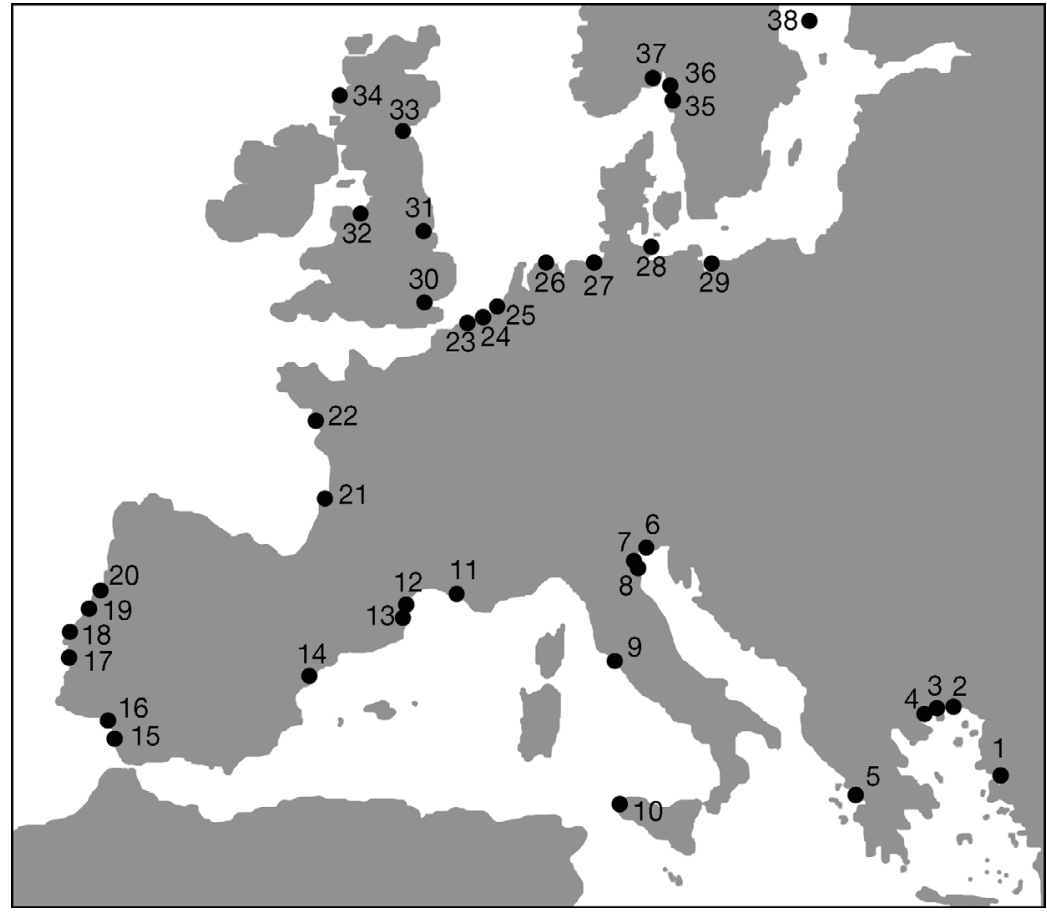

Fig. 1. Locations of the 38 estuaries considered in the present paper. 1: Koycegiz Lagoon-Estuarine system; 2: Porto-Lagos lagoon; 3: Strymon estuary; 4: Rihios estuary; 5: Messolonghi lagoon; 6: Venice Lagoon; 7: Sacca di Scardovari; 8: Sacca di Goro; 9: Fogliano-Caprolace coastal lakes; 10: Stagnone di Marsala; 11: Mauguio lagoon; 12: Sales-Leucate lagoon; 13: Canet-Saint-Nazaire lagoon; 14: Ebro estuary; 15: Bay of Cadiz; 16: Guadalquivir estuary; 17: Mira estuary; 18: Tagus estuary; 19: Óbidos; 20: Ria de Aveiro; 21: Gironde estuary; 22: Loire estuary; 23: Westerschelde; 24: Sheldt; 25: Oosterschelde; 26: Ems-Dollard; 27: Weser \& Elbe; 28: Darss-Zingster Bodden Chain; 29: Oderhaff/Stettin lagoon; 30: Thames estuary; 31: Humber estuary; 32: Mersey estuary; 33: Forth estuary; 34: Loch Etive; 35: Göta River; 36: Gullmarsfjord; 37: Oslofjord; 38: NW Åland
In the case of discrepancies (when the species was allocated to different groups in different estuarine areas), then a geographic/environmental criterion was used, assigning the species to the more frequent category across those estuarine areas similar to the one considered.

Following the guidelines by Elliott et al. (2007), the mode of feeding of fish species was related to the species while in its estuary. Hence, allocation to feeding categories was carried out only for those species intensively using the estuary as a feeding ground (i.e. estuine species and marine migrants). Each species was inned to a feeding category according to the availinformation was available, trophic preferences we inferred from species morphology (e.g. mouth and teeth morphology), behaviour and feeding habitat (e.g. pelagic, demersal). Assignment to feeding groups also considered the possible ontogenetic shift in the feeding preferences of a species (Elliott \& Hemingway 2002). When such a shift was reported, the species was assigned multiple feeding categories by equally weighting the contributions of the different dietary groups. For example, for Gobius niger Linnaeus, 1758, changing feeding from microbenthivore to hyperbenthivore/piscivore, a score of 0.5 was attributed to each of these groups to represent the single species in the estuary.

In order to understand the functioning of estuaries as breeding areas, species spawning in the estuarine environment (estuarine species) were allocated to reproductive categories. Marine migrants were assigned to reproductive groups as well, in order to highlight the adaptations of reproductive strategies to the different uses of the estuarine environment. Information on species reproductive ecology was used together with other ecological and morphological information (e.g. nest construction, presence of a body pouch, buoyant or sticky eggs) (Fischer et al. 1987, Gandolfi et al. 1991, Elliott \& Dewailly 1995, Gibson 2005, Froese \& Pauly 2006, Elliott et al. 2007).

Fish assemblage functional structure evaluation. The percentage contribution of each functional category to the total species richness was calculated for each estuary, and the averages were 
Table 1. European estuaries covered in the study and source of the main data sets

\begin{tabular}{|c|c|c|c|c|}
\hline Estuary & Country & Ecoregion & Latitude & Sources \\
\hline $\begin{array}{l}\text { Koycegiz Lagoon-Estuarine } \\
\text { system }\end{array}$ & Turkey & Mediterranean & $36^{\circ} \mathrm{N}$ & Akin et al. (2005) \\
\hline Porto-Lagos Lagoon & Greece & Mediterranean & $41^{\circ} \mathrm{N}$ & Koutrakis et al. (2005) \\
\hline Strymon Estuary & Greece & Mediterranean & $41^{\circ} \mathrm{N}$ & Koutrakis et al. (2000) \\
\hline Rihios Estuary & Greece & Mediterranean & $41^{\circ} \mathrm{N}$ & Koutrakis et al. (2000) \\
\hline Messolonghi Lagoon & Greece & \multicolumn{3}{|c|}{ Katselis et al. (2003) } \\
\hline Venice Lagoon & Italy & Mediterranean & $45^{\circ} \mathrm{N}$ & Mainardi et al. (2005), Franco et al. (2006) \\
\hline Sacca di Scardovari & Italy & Mediterranean & $45^{\circ} \mathrm{N}$ & Franzoi et al. (1989) \\
\hline Sacca di Goro & Italy & Mediterranean & $45^{\circ} \mathrm{N}$ & P. Franzoi (unpubl. data) \\
\hline $\begin{array}{l}\text { Lakes Fogliano-Caprolace } \\
\text { coastal lagoons }\end{array}$ & Italy & Mediterranean & $41^{\circ} \mathrm{N}$ & Mariani (2001) \\
\hline Stagnone di Marsala & Italy & Mediterranean & $37^{\circ} \mathrm{N}$ & Sarà et al. (1996) \\
\hline Mauguio Lagoon & France & Mediterranean & $43^{\circ} \mathrm{N}$ & Quignard et al. (1984) \\
\hline Sales-Leucate Lagoon & France & Mediterranean & $43^{\circ} \mathrm{N}$ & Hervé \& Bruslé (1980), Mouillot et al. (2007) \\
\hline Canet-Saint-Nazaire Lagoon & France & Mediterranean & $43^{\circ} \mathrm{N}$ & Hervé \& Bruslé (1981), Mouillot et al. (2007) \\
\hline Ebro Estuary & Spain & Mediterranean & $41^{\circ} \mathrm{N}$ & Elliott \& Hemingway (2002) \\
\hline Bay of Cadiz & Spain & Atlantic Ocean & $36^{\circ} \mathrm{N}$ & Elliott \& Hemingway (2002) \\
\hline Guadalquivir Estuary & Spain & Atlantic Ocean & $36^{\circ} \mathrm{N}$ & Elliott \& Hemingway (2002) \\
\hline Mira Estuary & Portugal & Atlantic Ocean & $41^{\circ} \mathrm{N}$ & Elliott \& Hemingway (2002) \\
\hline Tagus Estuary & Portugal & Atlantic Ocean & $39^{\circ} \mathrm{N}$ & $\begin{array}{l}\text { Elliott \& Dewailly (1995), Elliott \& Hemingway (2002), } \\
\text { Thiel et al. (2003) }\end{array}$ \\
\hline Óbidos & Portugal & Atlantic Ocean & $39^{\circ} \mathrm{N}$ & Elliott \& Hemingway (2002) \\
\hline Ria de Aveiro & Portugal & Atlantic Ocean & $40^{\circ} \mathrm{N}$ & $\begin{array}{l}\text { Elliott \& Dewailly (1995), Elliott \& Hemingway (2002) } \\
\text { Pombo et al. (2005) }\end{array}$ \\
\hline Gironde Estuary & France & Atlantic Ocean & $45^{\circ} \mathrm{N}$ & Lobry et al. (2003) \\
\hline Loire Estuary & France & Atlantic Ocean & $47^{\circ} \mathrm{N}$ & Elliott \& Dewailly (1995), Elliott \& Hemingway (2002) \\
\hline Westerschelde & Netherlands & North Sea & $51^{\circ} \mathrm{N}$ & Elliott \& Dewailly (1995), Elliott \& Hemingway (2002) \\
\hline Scheldt & Netherlands & North Sea & $51^{\circ} \mathrm{N}$ & Maes et al. (2005) \\
\hline Oosterschelde & Netherlands & North Sea & $51^{\circ} \mathrm{N}$ & Elliott \& Dewailly (1995), Elliott \& Hemingway (2002) \\
\hline Ems-Dollard & Netherlands & North Sea & $53^{\circ} \mathrm{N}$ & Elliott \& Hemingway (2002) \\
\hline Elbe Estuary & Germany & North Sea & $53^{\circ} \mathrm{N}$ & $\begin{array}{l}\text { Elliott \& Dewailly (1995), Thiel et al. (1995, 2003), } \\
\text { Thiel \& Potter (2001), Elliott \& Hemingway (2002) }\end{array}$ \\
\hline Darss-Zingster Bodden Chain & Germany & Baltic Sea & $54^{\circ} \mathrm{N}$ & Elliott \& Hemingway (2002) \\
\hline Oderhaff/Stettin Lagoon & Germany & Baltic Sea & $54^{\circ} \mathrm{N}$ & Elliott \& Hemingway (2002) \\
\hline Thames Estuary & UK, England & North Sea & $51^{\circ} \mathrm{N}$ & Elliott \& Hemingway (2002) \\
\hline Humber Estuary & UK, England & North Sea & $54^{\circ} \mathrm{N}$ & Marshall \& Elliott (1996), Elliott \& Hemingway (2002) \\
\hline Mersey Estuary & UK, England & Atlantic Ocean & $53^{\circ} \mathrm{N}$ & Elliott \& Dewailly (1995), Elliott \& Hemingway (2002) \\
\hline Forth Estuary & UK, Scotland & North Sea & $56^{\circ} \mathrm{N}$ & $\begin{array}{l}\text { Elliott \& Taylor (1989), Elliott et al. (1990), } \\
\text { Elliott \& Dewailly (1995), Elliott \& Hemingway (2002) }\end{array}$ \\
\hline Loch Etive & UK, Scotland & Atlantic Ocean & $56^{\circ} \mathrm{N}$ & Elliott \& Hemingway (2002) \\
\hline Göta River & Sweden & North Sea & $58^{\circ} \mathrm{N}$ & Elliott \& Hemingway (2002) \\
\hline Gullmarsfjord & Sweden & North Sea & $58^{\circ} \mathrm{N}$ & Elliott \& Hemingway (2002) \\
\hline Oslofjord & Norway & North Sea & $59^{\circ} \mathrm{N}$ & Nash (1988), Elliott \& Dewailly (1995) \\
\hline NW Åland & Sweden & Baltic Sea & $60^{\circ} \mathrm{N}$ & Elliott \& Hemingway (2002) \\
\hline
\end{tabular}

compared among groups, in order to assess the prevailing habitat-use, feeding and reproductive strategies adopted by fish species in European estuaries. Multiple and pairwise differences were tested by non-parametric statistics (Kruskal-Wallis and Mann-
Whitney tests) in STATISTICA (StatSoft 2004). Variability in the different guild contributions was assessed by computing the coefficient of variation (in percent) $(\mathrm{CV}=100 \times \mathrm{SD} / \mathrm{mean})$ on percentage data for each functional group. 
The variability in the functional structure of fish assemblages across European estuaries was also investigated by a cluster analysis carried out on the BrayCurtis similarity matrix derived from the whole data set on the percentage number of species per guild by estuary (taking into account only estuarine species for the calculation of the reproductive guild contribution). A similarity profile analysis (SIMPROF, with $\mathrm{p}=5 \%$ and no. of permutations $=9999$ ) was also conducted in order to test for the presence of an actual structure (clustering) among samples due to differences in the functional composition of fish assemblages. This analysis performs permutation tests at every node of the completed dendrogram, looking for statistically significant evidence of genuine clusters in samples which are a priori unstructured (Clarke \& Gorley 2006). Multivariate analyses were carried out using PRIMER 6 software (Clarke \& Gorley 2006).

\section{RESULTS}

A total of 317 fish taxa (313 species and 4 genera) were considered from the 38 European estuaries (Table A4 of Appendix 1, available in MEPS Supplementary Material at www.int-res.com/articles/suppl/m354p219_app. pdf). The fish assemblage species richness varied from 16 (Canet-Saint-Nazaire lagoon) to 110 (Thames estuary), with an average $( \pm$ SD) of $53 \pm 20$.

In terms of habitat use, the European estuarine fish assemblages were significantly dominated by marine species, either migrants and stragglers, followed by estuarine, freshwater, anadromous and catadromous species ( $\mathrm{n}=228, H=129.5, \mathrm{p}<0.001$ ) (Table A5 of Appendix 1, available in MEPS Supplementary Material at www.int-res.com/articles/suppl/m354p219_app.pdf). The freshwater group was the most variable, with proportions of species ranging from 0 (Bay of Cadiz, Fogliano-Caprolace lagoons, Stagnone di Marsala, Óbidos lagoon, Forth estuary) to 58\% (Oderhaff/ Stettin lagoon), as shown by CV values (Appendix 1: Table A5). Conversely, marine migrant and estuarine groups showed the lowest variability in terms of their contribution across the investigated European estuarine assemblages, ranging from 8\% (Oderhaff/Stettin lagoon) to $51.7 \%$ (Fogliano-Caprolace lagoons), and from $2.6 \%$ (Koycegiz system) to $30 \%$ (Sacca di Goro and Oslofjord), respectively (Appendix 1: Table A5).

Estuarine species showed a significant trophic preference towards smaller sized benthic and planktonic prey caught on the bed or in the water layer just above it ( $\mathrm{n}=304, H=195.9, \mathrm{p}<0.001$ ), as microbenthivores and hyperbenthivores/zooplanktivores dominated the assemblage (Appendix 1: Table A5). Within the marine migrant group, species richness appeared more dis- tributed across feeding categories, but nevertheless a highly significant difference was detected ( $\mathrm{n}=304, H=$ 123.5, p < 0.001): hyperbenthivores/piscivores, microand macrobenthivores, planktivores and detritivores dominated the assemblage (Appendix 1: Table A5). In both estuarine and marine migrant assemblages, the herbivore group was low ranked and highly variable in terms of relative species abundance (Appendix 1: Table A5). Within the estuarine group, herbivores occurred only in the Stagnone di Marsala lagoon, and here were only represented by Parablennius sanguinolentus (Pallas, 1814), accounting for $8.3 \%$ of the total species richness. As regards the marine migrants, herbivorous species were recorded only in the Guadalquivir estuary and Bay of Cadiz (Hyporhamphus picarti [Valenciennes, 1847]), and in the Mauguio lagoon (Sarpa salpa [Linnaeus, 1758]). The detritivores also had a low rank and a high variability in the estuarine species assemblage (Appendix 1: Table A5). This feeding category was recorded only in the Ria de Aveiro lagoon, its only representative being the mullet Mugil cephalus Linnaeus, 1758, which, in this system only, was allocated to the estuarine species group. The comparison between estuarine and marine migrant assemblages highlighted highly significant differences for almost all of the feeding categories ( $p<0.001$ ), except for herbivores and omnivores, which were always low ranked in their contribution to these assemblages (Appendix 1: Table A5). Microbenthivores and hyperbenthos/zooplankton feeders were represented to a greater degree in the estuarine species group, whereas the remaining feeding groups prevailed among marine migrant species (Appendix 1: Table A5).

Different reproductive strategies occurred between estuarine and migrant assemblages. The estuarine species group was significantly dominated by oviparous guarders, followed by species sheltering their eggs or attaching them to the substratum ( $\mathrm{n}=228, H=$ 151.6, p < 0.001; Appendix 1: Table A5). By contrast, oviparous species with pelagic eggs dominated the migrant assemblage, followed by those species laying their eggs over or attached to the substratum ( $\mathrm{n}=228$; $H=168.2, \mathrm{p}<0.001$; Appendix 1: Table A5). All of these reproductive modes showed low variability in the estuarine use category, where they dominated, with a CV always < $100 \%$ (Appendix 1: Table A5). Conversely, oviparous species with pelagic eggs was the most variable group within the estuarine category (Appendix 1: Table A5), with its contribution varying from 0 (in 28 estuaries out 38) to $11 \%$ (in Messolonghi lagoon, with Pegusa impar [Bennett, 1831] as the only estuarine species). In turn, shelterers and viviparous species were the most variable groups in the marine migrant assemblage, followed by guarders (Appendix 1: 
Table A5). The percentage number of shelterer species among marine migrants ranged from 0 (in 34 out 38 estuaries) to $9.5 \%$ (in the Venice Lagoon, with the migrant pipefishes Syngnathus acus Linnaeus, 1758 and $S$. tenuirostris Rathke, 1837 as representatives), whereas the contribution of viviparous varied from 0 (in 34 out 38 estuaries) to $4.3 \%$ (in the Oosterschelde, with Dasyatis pastinaca [Linnaeus, 1758] and Zoarces viviparus [Linnaeus, 1758] as representatives). Guarders were found among marine migrants in only 13 estuaries out of 38 , with their maximum contribution $(16.7 \%)$ in the Darss-Zingster and NW Åland estuaries, where they were represented by Cyclopterus lumpus Linnaeus, 1758. Differences in the reproductive strategy between the 2 estuarine use categories were confirmed by statistical comparisons for all reproductive groups (always $\mathrm{p}<0.01$ ), with oviparous species laying their eggs in the water (pelagic eggs) or over the substratum (demersal eggs) being more abundant among marine migrants, and the remaining groups prevailing among estuarine species (Appendix 1: Table A5).

Cluster and SIMPROF analyses highlighted a certain variability in the functional structure of fish assemblages across European estuaries, with the presence of 9 different clusters (Fig. 2). The Koycegiz LagoonEstuarine system (Cluster A) was distinguished from the other estuaries by the dominance of marine stragglers (56\%) and, among species feeding and spawning in the system, by detritivores (46\%) and oviparous species with adhesive eggs (100\%). Clusters B and C, grouping all the Baltic estuaries, were characterised by a high contribution of freshwater species (58 and $40 \%$, respectively) to the fish assemblage, with also anadromous species abundant in the Oderhaff/Stettin lagoon (Cluster B), followed by estuarine species (16 and 26\% in Clusters B and C, respectively). High relative numbers of microbenthivores (21 to $25 \%$ ), hyperbenthos/zooplankton feeders (25 to $33 \%$ ), planktivores (15 to $25 \%$ ) and guarder species (37 to $50 \%$ ) were also found in these samples. In the other estuaries (Clusters D to I), marine species, either migrants or stragglers, dominated the fish assemblages, accounting for 30 to $40 \%$ of the total species richness, and microbenthivory and external guarding of eggs were the most highly represented strategies, with relative contributions of these guilds ranging from 27 to $31 \%$ and 39 to $52 \%$, respectively. However, the analysis detected some differences also among these samples. A high contribution of detritivores (32\%) distinguished Cluster E (Mediterranean estuaries), whereas high relative numbers of freshwater species ( $21 \%$ ) and of shelterer species ( $41 \%$ on average) characterised assemblages from Cluster F (including estuaries from the Atlantic seaboard and North Sea). Fish assemblages from Cluster G (North Sea and Atlantic estuaries) were dominated by marine stragglers (36\%), followed by estuarine and marine migrant species (27 and $26 \%$ ). High relative numbers of hyperbenthos/fish feeders and macrobenthivores (about $20 \%$ each) characterised Clusters G and H (North Sea and Atlantic estuaries), with oviparous species with adhesive eggs also abundant in the latter $(21 \%)$. Cluster I (Mediterranean estuaries) was also typified by the presence of numerous freshwater species (20\%), detritivores (28\%) and oviparous species with adhesive eggs (37\%).

\section{DISCUSSION}

\section{The guild approach}

The guild approach, going beyond the strictly systematic level, allows a greater understanding of estuarine functioning, by separating estuarine use strategies adopted by fishes from accidental behaviours (Elliott et al. 2007). However, this approach at present requires an investigator's best judgement in assigning guilds based on available knowledge, which in turn increases variability, unless the guilds are rigorously defined (Gerking 1994), and hence the number of attempts at classifying estuarine fishes (Blaber 2002). Elliott et al. (2007), while standardising the terms, recommended that their objectivity required testing on large data sets, hence the motivation for the present study. In addition, the life-history adaptability of spe-

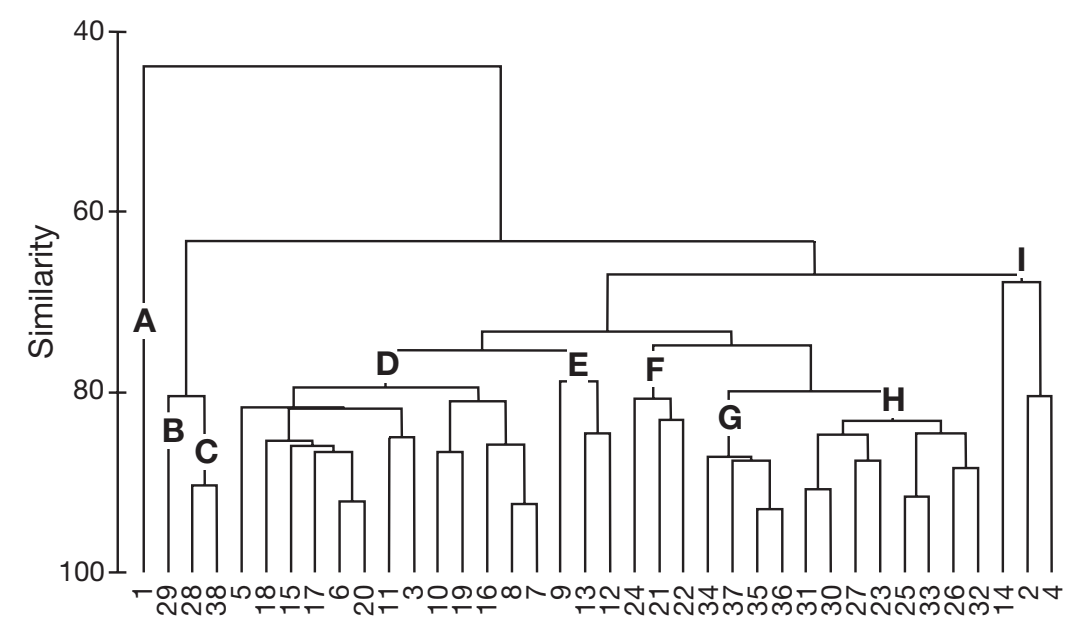

Fig. 2. Cluster analysis of the 38 European estuaries (designated by number as in Fig. 1) based on the overall functional structure of estuarine fish assemblages. Groupings identified by SIMPROF analysis are indicated by capital letters 
cies may create further difficulties in applying guilds, especially when assigning a species to the same guild in every environment where it is encountered (as suggested by Elliott \& Dewailly 1995). The guild approach as used here has greatly progressed from this idea, by relying on a 'flexible' allocation criterion, which takes into account the possible different functional roles that a species may have in different estuaries (local adaptations) or in different stages of its life cycle (ontogenetic shifts, e.g. in the diet) (Gerking 1994). This approach has the advantage of reflecting the opportunistic and variable functioning of estuaries, but, on the other hand, requires the knowledge of species biology and their adaptations for each estuarine area. This information, as shown here, is not always available, such that subjective choices must nevertheless be made (e.g. to assign species to the more frequent designation encountered). However, we believe that the degree of subjectivity is significantly reduced in the present guild approach with respect to the adoption of rigid assignment criteria.

The selectivity of sampling methods towards certain guilds may also introduce bias (Elliott \& Dewailly 1995, Elliott \& Hemingway 2002). The estuaries included here were sampled mainly by bed trawling or netting over the bed, methods which could underestimate the number of pelagic or planktivorous species (Elliott \& Dewailly 1995). However, Elliott et al. (1990) showed that bed trawling in shallow estuarine areas takes a representative pelagic population, at both qualitative and quantitative levels (Elliott \& Dewailly 1995). Furthermore, as this study relied on a qualitative approach (species occurrence), some differences are expected when applying it to quantitative information (species abundances). For example, marine stragglers are typically represented by high numbers of species, but very low numbers of individuals (Elliott et al. 1990), while planktivorous species may be highly represented owing to the large numbers of, e.g., clupeoids, which inhabit estuaries for part of the year (Elliott \& Dewailly 1995).

\section{The ecology of fishes in European estuaries}

The present study shows that European estuaries are mostly used as temporary habitats by fish, as feeding or nursery grounds. The marine components are the dominant contributors to the diversity of estuarine fish fauna (58\% on average), as indicated also by McLusky \& Elliott (2004). In turn, relatively few species use European estuaries for spawning or reside permanently in them (19\%), and even fewer use them for diadromous migrations (9\%). Previous studies on European and tropical estuaries reported the estuarine guild as contributing most to the fish fauna (Elliott \& Dewailly 1995, Blaber 2002, Elliott \& Hemingway 2002). This difference may be ascribed mainly to a different guild categorisation, as regards the European studies, or to the difficulties in placing species into estuarine-dependent and non-dependent categories in tropical areas (Blaber 1997, 2002).

The dominance of temporary users of the estuarine environment reinforces the concept that the relatively harsh conditions in estuaries challenge the physiological mechanisms of most species, especially marine, stenohaline species, thus excluding many from permanent residency in these systems (McLusky \& Elliott 2004, Elliott \& Quintino 2007). Hence, for those few species that can adapt to this environment and permanently tolerate the conditions (i.e. estuarine species), it represents an escape from competition in the sea or in freshwater (McLusky \& Elliott 2004) and is thus regarded as an ecological subsidy rather than a stress (Elliott \& Quintino 2007). At the same time, sheltered estuarine habitats offer high densities of prey and other food not encountered in marine areas, and their turbid shallow waters provide protection from predators (Blaber 1997, McLusky \& Elliott 2004). These favourable conditions, particularly for postlarvae and juveniles, represent the most likely causes for estuarine usage by fish, leading also to migrations into estuarine habitats of those marine species with an ability to tolerate the conditions (Blaber 1997, McLusky \& Elliott 2004). Hence, for marine and estuarine species our results reinforce the nature of the estuarine ichthyofauna along a stress-subsidy continuum (Elliott \& Quintino 2007). This is also shown, but to a lesser extent, with freshwater-derived species, which in European estuaries represent $14 \%$ of the total richness. Their contribution is highly variable, depending on the large variability of freshwater inflows in the different estuarine areas. In fact, while no such species are present in areas where freshwater inputs are almost zero (e.g. the Stagnone di Marsala; Mazzola et al. 2001), they dominate fish assemblages from the Baltic Sea, a semi-enclosed brackish body of water strongly influenced by river runoff (HELCOM 1993).

The guild approach results confirm the important role of fish in linking the benthic and pelagic food webs in European estuaries (Elliott \& Hemingway 2002). Small-sized benthic, epibenthic and hyperbenthic prey (e.g. mysids, shrimps, amphipods, larvae of fishes), in particular, are the predominant food of estuarine species, according to their small size and benthic or demersal habits (Elliott \& Dewailly 1995). Also, marine migrants significantly feed on hyperbenthos, with an ontogenetic shift from smaller to larger benthic prey and/or to fish. Hence, our findings validate the guild approach by reinforcing the general characteris- 
tics of estuarine food webs, e.g. a primary dependence by fishes on the detrital food web in temperate estuaries (Day et al. 1981) and, at the same time, the tendency for most fish to feed either directly or indirectly on detritivorous invertebrates, more than on detritus itself (Wootton 1992). Detritivory, in fact, is infrequent in fishes from European estuaries, although a large variability has been observed across areas. This feeding guild, which in the studied area is constituted by grey mullets, is particularly represented (sometimes dominant) in Mediterranean coastal lagoons. Although Gerking (1994) suggests that detritus-feeding habits in fishes evolve more often at lower latitudes, our result is likely to be ascribed mainly to the geographical distribution of grey mullets, which, although being widespread over Europe, are more common along warmer coasts (Tortonese 1975, Miller \& Loates 1997). In addition, the presence of extensive vegetated habitats (e.g. saltmarshes, seagrasses) in the Mediterranean lagoons, as suggested by the higher relative number of oviparous fish species attaching their eggs to submerged vegetation, may possibly enhance detritus availability in these warm-temperate environments, thus attracting more detritivorous species.

The pelagic domain is also important for fish feeding in European estuaries, although it may be indistinguishable from the demersal compartment, due to the shallow nature of most estuarine habitats and the high dynamic characteristics leading to bed resuspension. Relatively large numbers of both estuarine and marine migrant species in European estuaries prey on zooplankton, which feed extensively on phytoplankton/ resuspended microphytobenthos and particulate organic matter, again important food sources in estuaries (Elliott \& Hemingway 2002). Plankton feeders are particularly abundant in estuaries from the Baltic and North Seas, highly productive ecosystems where small planktotrophic pelagic species (e.g. clupeoids) abound (Anonymous 2007). By contrast, herbivory is an infrequent and highly variable feeding mode in European estuaries $(<1 \%$ of the total species richness). Species richness of herbivorous fishes is reported to decrease with latitude, despite the often high standing stocks of macroalgae available in temperate areas, and the causes are largely unknown (Horn \& Ojeda 1999, Horn \& Ferry-Graham 2006). Hamerlin-Vivien (2002) suggests a need for more energy-rich (i.e. animal) food sources at higher latitudes, where lower temperatures limit food-processing rates. In turn, the large variability of herbivore contribution to fish species richness in European estuaries may possibly be ascribed to differences in the availability of their feeding habitats, such as hard substrata colonised by encrusting algae or shallow water where macrovegetation can persist (Wootton 1992).
Most estuarine species (>90\%) in European transitional environments spawn demersal eggs, attach them to the substratum and give parental care (guarding eggs in nests or internal brooding). These are common adaptations by estuarine fish to prevent seaward flushing of eggs and larvae (Elliott \& Dewailly 1995, Wootton 1999, Rountree \& Able 2007). Large egg size and a long egg stage, leading to a lack of (or reduced) planktonic larval stage, typify this retention strategy (Elliott \& Hemingway 2002, McLusky \& Elliott 2004). In addition, guarding and tending of a spawning site by the parental fish (as in gobies) or sheltering the eggs in a body pouch (as in pipefishes) are common behaviours in estuarine fishes, as they improve significantly offspring survival in conditions of spatial and temporal unpredictability (Wootton 1999). Hence, our study shows the estuarine value of the optimisation theory whereby parental care involves increased investment per offspring (hence, larger individual offspring) at the expense of the number of offspring in which the total investment is made (DeMartini \& Sikkel 2006). The most extreme example of parental care is matrotrophic viviparity (DeMartini \& Sikkel 2006), an uncommon strategy in European estuaries. The viviparous blenny Zoarces viviparus, found in most northern European transitional waters, provides the only example of this reproductive mode.

The reproductive strategy of marine migrant fish in European estuaries is completely different from that of the estuarine residents, as $>70 \%$ of these species spawn pelagic eggs, followed by species laying demersal eggs, either settling on the substratum or attached to it. Dispersion of pelagic eggs is usually associated with small egg size, large numbers of eggs and extended pelagic larval period (Elliott \& Hemingway 2002), and typically characterises offshore marine species (Wootton 1999). A pelagic planktotrophic larval period is trophically advantageous outside the estuaries (Balon 1984, Elliott \& Hemingway 2002). Many marine-spawning estuarine fishes, then, have evolved particular dispersal mechanisms (e.g. the selective tidal stream transport in flounders), which deliver juveniles from offshore breeding areas into estuarine nursery grounds (McLusky \& Elliott 2004).

\section{CONCLUSIONS}

Although previous studies (e.g. Elliott \& Dewailly 1995) highlighted the relatively high similarity between estuaries based on functional guilds and thus average functional structure of fish assemblages, the present study was required to test the ideas on a larger data set. A temporal resource partitioning of estuarine habitat use has been observed, which is likely to allow 
these environments to support more species than would otherwise be possible (Rountree \& Able 2007). Furthermore, marine species temporarily using estuarine habitats play a role in the ecological connectivity between the 2 environments, via the transport of local production to the marine waters (a broader view of Kneib's 'trophic relay' concept; Kneib 2000). The benthic-demersal compartment, in particular, supports the functioning of estuarine ecosystems, by providing resources for fish living, feeding and reproducing, both in terms of space and food. Our findings, by increasing knowledge on fish life strategies in transitional environments, validate the functional guild approach using a pan-continental data set; this consequently produces a valuable tool in investigating the general functioning of estuaries through the life-style adaptations of fish species. This increases further applications of this approach, e.g. in the field of the European Water Framework Directive, as it may provide valuable information on the ecological status of European transitional water bodies. Of course, the variability in the functional structure of fish assemblages across estuaries, highlighted here as in previous studies (Elliott \& Dewailly 1995, Elliott \& Hemingway 2002, Lobry et al. 2003), needs to be further investigated and related to the changing environment and degree of human impacts in estuaries. These studies are fundamental in defining reference functional conditions for different types of transitional water bodies, a critical aspect in the Water Framework Directive in Europe and the Clean Water Act in the United States in evaluating deviation from normal ecological status as the result of anthropogenic factors.

\section{LITERATURE CITED}

Able KW (2005) A re-examination of fish estuarine dependence: evidence for connectivity between estuarine and ocean habitats. Estuar Coast Shelf Sci 64:5-17

Akin S, Buhan E, Winemiller KO, Yilmaz H (2005) Fish assemblage structure of Koycegiz Lagoon-Estuary, Turkey: spatial and temporal distribution patterns in relation to environmental variation. Estuar Coast Shelf Sci 64:671-684

Anonymous (2007) Large marine ecosystems of the world. Available at http://woodsmoke.edc.uri.edu/Portal

Balon EK (1981) Additions and amendments to the classification of reproductive styles in fishes. Environ Biol Fish 6: 377-389

Balon EK (1984) Patterns in the evolution of reproductive styles in fishes. In: Potts GW, Wootton RJ (eds) Fish reproduction: strategies and tactics. Academic Press, London, p 35-53

Blaber SJM (1997) Fish and fisheries of tropical estuaries. Chapman \& Hall, London

Blaber SJM (2002) Fish in hot water: the challenges facing fish and fisheries research in tropical estuaries. J Fish Biol 61(Suppl A):1-20

Blondel J (2003) Guilds or functional groups: Does it matter? Oikos 100:223-231

Clarke KR, Gorley RN (2006) PRIMER V6: user manual/tutorial.
PRIMER-E, Plymouth

Day HJ, Blaber SJM, Wallace JH (1981) Estuarine fishes. In: Day HJ, Blaber SJM, Wallace JH (eds) Estuarine ecology. A.A. Balkema, Cape Town, p 197-221

DeMartini EE, Sikkel PC (2006) Reproduction. In: Allen LG, Pondella II DJ, Horn MH (eds) The ecology of marine fishes-California and adjacent waters. University of California Press, San Francisco, CA, p 483-523

Elliott M, Dewailly F (1995) The structure and components of European estuarine fish assemblages. Neth J Aquat Ecol 29:397-417

Elliott M, Hemingway KL (2002) Fishes in estuaries. Blackwell Science, London

Elliott M, Quintino VM (2007) The estuarine quality paradox, environmental homeostasis and the difficulty of detecting anthropogenic stress in naturally stressed areas. Mar Pollut Bull 54:640-645

Elliott M, Taylor CJL (1989) The structure and functioning of an estuarine/marine fish community in the Forth Estuary, Scotland. In: Klekowski RZ, Styczyńska-Jurewicz E, Falkowski L (eds) Proc 21st Eur Mar Biol Symp. Polish Academy of Sciences, Institute of Oceanology, Gdańsk, p 227-240

Elliott M, O'Reilly MG, Taylor CJL (1990) The Forth estuary: a nursery and overwintering area for North Sea fishes. Hydrobiologia 195:89-103

Elliott M, Whitfield AK, Potter IC, Blaber SJM, Cyrus DP, Nordlie FG, Harrison TD (2007) The guild approach to categorizing estuarine fish assemblages: a global review. Fish Fish 8:241-268

Eschmeyer WN (2004) Catalog of fishes. Available at: www. calacademy.org/research/ichthyology/catalog/fishcatsearch. html

Fischer W, Schneider M, Bauchot ML (1987) Fiches FAO d'identification des especies pour le besoins de la peche, Mediterranee et Mer Noire, zone de peche 37, Vol II, Vertebres. FAO, Rome

Franco A, Franzoi P, Malavasi S, Riccato F, Torricelli P (2006) Use of shallow water habitats by fish assemblages in a Mediterranean coastal lagoon. Estuar Coast Shelf Sci 66: 67-83

Franzoi P, Trisolini R, Carrieri A, Rossi R (1989) Caratteristiche ecologiche del popolamento ittico ripario della sacca di Scardovari (Delta del Po). Nova Thalassia 10 (Suppl 1): 399-405

Froese R, Pauly D (2005) FishBase. Available at: http://fishbase.org

Gandolfi G, Zerunian S, Torricelli P, Marconato A (1991) I pesci delle acque interne italiane, Parte 3. Riconoscimento, biologia, distribuzione e status delle specie. Istituto Poligrafico e Zecca dello Stato, Rome

Garrison LP, Link JS (2000) Dietary guild structure of the fish community in the Northeast United States continental shelf ecosystem. Mar Ecol Prog Ser 202:231-240

Gerking SD (1994) Feeding variability. In: Gerking SD (ed) Feeding ecology of fish. Academic Press, San Diego, CA, p $41-53$

Gibson RN (2005) Flatfishes. Biology and exploitation. Blackwell Science, Oxford

Hamerlin-Vivien ML (2002) Energetics and fish diversity on coral reefs. In: Sale PF (ed) Coral reef fishes: dynamics and diversity in a complex ecosystem. Academic Press, San Diego, CA, p 265-274

HELCOM (Helsinki Commission) (1993) The Baltic Sea joint comprehensive environmental action programme. Balt. Sea Environ. Proc. No. 48, HELCOM, Helsinki. Available at: www.baltic.vtt.fi/demo/balful.html 
Hervé P, Bruslé J (1980) L'étang de Salses-Leucate, écologie générale et ichtyofaune. Vie Milieu 30:275-283

Hervé P, Bruslé J (1981) L'étang de Canet-Saint-Nazaire (P.O.), écologie générale et ichtyofaune. Vie Milieu 31:17-25

Horn MH, Ferry-Graham LA (2006) Feeding mechanisms and trophic interactions. In: Allen LG, Pondella II DJ, Horn MH (eds) The ecology of marine fishes - California and adjacent waters. University of California Press, San Francisco, CA, p 387-410

Horn MH, Ojeda FP (1999) Herbivory. In: Horn MH, Martin KLM, Chotkowsky MA (eds) Intertidal fishes - Life in two worlds. Academic Press, New York, p 197-222

Katselis G, Koutsikopoulos C, Dimitriou E, Rogdakis Y (2003) Spatial patterns and temporal trends in the fishery landings of the Messolonghi-Etoliko lagoon system (western Greek coast). Sci Mar 67:501-511

Kneib RT (2000) Salt marsh ecoscapes and production transfers by estuarine nekton in the southeastern United States. In: Weinstein MP, Kreeger DA (eds) Concepts and controversies in tidal marsh ecology. Kluwer Academic Press, Dordrecht, p 267-291

Koutrakis ET, Kokkinakis AK, Eleftheriadis EA, Argyropoulou MD (2000) Seasonal changes in distribution and abundance of the fish fauna in the two estuarine systems of Strymonikos Gulf (Macedonia, Greece). Belg J Zool 130:41-48

Koutrakis ET, Tsikliras AC, Sinis AI (2005) Temporal variability of the ichthyofauna in a northern Aegean coastal lagoon (Greece). Influence of environmental factors. Hydrobiologia 543:245-257

Leonardos I, Sinis A, Kokkinidou A (2000) Fish fauna of the Messolongi and Etolikon Lagoons. Proc 6th Hellenic Symp Oceanogr Fish, May 23-26, Chios. NCMR, Athens, p 239-244

Lobry J, Mourand L, Rochard E, Elie P (2003) Structure of the Gironde estuarine fish assemblages: a comparison of European estuaries perspective. Aquat Living Resour 16:47-58

Maes J, Stevens M, Ollevier F (2005) The composition and community structure of the ichthyofauna of the upper Scheldt estuary: synthesis of a 10-year data collection (1991-2001). J Appl Ichthyol 21:86-93

Mainardi D, Fiorin R, Franco A, Franzoi P and others (2005) Composition and distribution of fish assemblages in the shallow waters of the Venice Lagoon. In: Campostrini P (ed) Scientific research and safeguarding of Venice, Corila Research: Program 2002 results. Multigraf, Venice, p 405-419

Mariani S (2001) Can spatial distribution of ichthyofauna describe marine influence on coastal lagoons? A central Mediterranean case study. Estuar Coast Shelf Sci 52: 261-267

Marshall S, Elliott M (1996) The structure of the fish assemblage in the Humber estuary, United Kingdom. Publ Espec Inst Esp Oceanogr 21:231-242

Mazzola A, Sarà G, Michener RH (2001) The use of carbon stable isotope to investigate the origin and distribution of suspended and sedimentary organic matter in a semienclosed Mediterranean marine system. In: Faranda FM, Guglielmo L, Spezie G (eds) Mediterranean ecosystems: structures and processes. Springer Verlag, New York, p 105-113

McLusky DS, Elliott M (2004) The estuarine ecosystem: ecology, threats and management, 3rd edn. Oxford University Press, Oxford

Editorial responsibility: Howard Browman, Storebø, Norway
McLusky DS, Elliott M (2007). Transitional waters: A new approach, semantics or just muddying the waters? Estuar Coast Shelf Sci 71:359-363

Miller PJ, Loates MJ (1997) Fishes of Britain and Europe. Harper Collins Publishers, London

Mouillot D, Dumay O, Tomasini JA (2007) Limiting similarity, niche filtering and functional diversity in coastal lagoon fish communities. Estuar Coast Shelf Sci 71: $443-456$

Nash RD (1988) The effects of disturbance and severe seasonal fluctuations in environmental conditions of north temperate shallow-water fish assemblages. Estuar Coast Shelf Sci 26:123-135

Nordlie FG (2003) Fish communities of estuarine salt marshes of eastern North America, and comparisons with temperate estuaries of other continents. Rev Fish Biol Fish 13: $281-325$

Pombo L, Elliott M, Rebelo EJ (2005) Environmental influences on fish assemblage distribution of an estuarine coastal lagoon, Ria de Aveiro (Portugal). Sci Mar 69:143-159

Potter IC, Beckley LE, Whitfield AK, Lenanton RCJ (1990) Comparisons between the roles played by estuaries in the life cycles of fishes in temperate western Australian and southern Africa. Environ Biol Fish 28:143-178

Quignard JP, Man Wai R, Vianet R (1984) Les poissons de l'étang de Mauguio (Hérault, France) inventaire, structure du peuplement, croissance et polymorphisme des tailles. Vie Milieu 34:173-183

Root RB (1967) The niche exploitation pattern of the blue-gray gnatcatcher. Ecol Monogr 37:317-350

Rountree RA, Able KW (2007) Spatial and temporal habitat use patterns for salt marsh nekton: implications for ecological functions. Aquat Ecol 41:25-45

Sarà G, Mirto S, Mazzola A (1996) Analisi della diversità biologica del popolamento ittico di una laguna costiera siciliana (Stagnone di Marsala, Sicilia occidentale). Biol Mar Mediterr 3:94-102

StatSoft (2004) Electronic statistics textbook. StatSoft, Tulsa, OK. Available at: www.statsoft.com/textbook/stathome. html

Stergiou KI, Karpouzi VS (2002) Feeding habits and trophic levels of Mediterranean fish. Rev Fish Biol Fish 11: 217-254

Thiel R, Potter IC (2001) The ichthyofaunal composition of the Elbe Estuary: an analysis in space and time. Mar Biol 138: 603-616

Thiel R, Sepulveda A, Kafemann R, Nellen W (1995) Environmental factors as forces structuring the fish community of the Elbe Estuary. J Fish Biol 46:47-69

Thiel R, Cabral H, Costa MJ (2003) Composition, temporal changes and ecological guild classification of the ichthyofaunas of large European estuaries - a comparison between the Tagus (Portugal) and the Elbe (Germany). J Appl Ichthyol 19:330-342

Tortonese E (1975) Fauna d'Italia, Osteichthyes. Calderini, Bologna

Whitfield AK (1994) Fish species diversity in southern African estuarine systems: an evolutionary perspective. Environ Biol Fish 40:37-48

Wootton RJ (1992) Fish ecology. Blackie \& Son, Glasgow

Wootton RJ (1999) Ecology of teleost fishes, 2nd edn. Kluwer Academic Publishers, Dordrecht

Submitted: January 23, 2007; Accepted: August 5, 2007

Proofs received from author(s): January 28, 2008 